Int. J. Plant Sci. 165(4):691-694. 2004.

(c) 2004 by The University of Chicago. All rights reserved.

1058-5893/2004/16504-0019\$15.00

\title{
A FOSSIL BYBLIDACEAE SEED FROM EOCENE SOUTH AUSTRALIA
}

\author{
John G. Conran ${ }^{1, *}$ and David C. Christophel ${ }^{*,} \dagger$ \\ ${ }^{*}$ Centre for Evolutionary Biology and Biodiversity, Environmental Biology, School of Earth and \\ Environmental Sciences, Darling Building DP418, University of Adelaide, South Australia \\ 5005, Australia; and tDepartment of Biological Sciences, University of Denver, \\ 2190E Iliff Avenue, Denver, Colorado 80210, U.S.A.
}

\begin{abstract}
A single mummified angiosperm seed is described from a middle Eocene clay lens deposit at the Monier East Yatala Sand Pit, Golden Grove, South Australia. The seed is small $(0.7 \mathrm{~mm}$ long and $0.45 \mathrm{~mm}$ wide), elliptical, black, and shows complex raised reticulate honeycomb sculpturing with deeply excavated cell floors and verrucate sculpturing on the anticlinal ridges. The fossil was compared against extant species of Byblis and the Droseraceae, especially the Drosera indica L. complex, common annual carnivorous plants that grow in seasonally damp environments in northern Australia and that have similarly small sculptured seeds. The combination of deep reticulately honeycombed cells and the verrucate anticlinal walls places the seed close to extant taxa in the Byblis liniflora Salisb. complex. However, in the absence of a larger sample and/or of definitive features to assign the fossil unequivocally to an extant species, as well as nomenclatural restrictions preventing the typification of a fossil by an illustration, the specimen is described as a parataxon and placed in Byblidaceae but without a formal name.
\end{abstract}

Keywords: Byblidaceae, fossil, seed, Eocene, South Australia, carnivorous plant.

\section{Introduction}

The Eocene floras of southern Australia have yielded a wealth of mummified leaves, flowers, and fruits for numerous mostly woody rainforest families (e.g., Christophel and Greenwood 1987, 1988; Christophel et al. 1987, 1992; Hill 1982, 1994). Nevertheless, there is evidence at some Eocene sites for the beginnings of xeromorphic adaptation and for possibly seasonal or monsoonal climates (Greenwood 1996; Hill and Brodribb 2001).

In 1986, a middle Eocene fossiliferous clay lens was discovered at the Monier East Yatala Sand Pit, Golden Grove, South Australia $\left(138^{\circ} 43^{\prime} 30^{\prime \prime} \mathrm{E}, 34^{\circ} 47^{\prime} 10^{\prime \prime} \mathrm{S}\right)$, ca. $25 \mathrm{~km}$ northeast of the city of Adelaide. This deposit was rich in leaves, flowers, and fruits of a wide range of rainforest taxa including the dicotyledonous families Elaeocarpaceae, Lauraceae, Myrtaceae, Proteaceae, Sterculiaceae, the monocotyledon Paracordyline (Laxmanniaceae), the gymnosperm family Podocarpaceae, and a fern in the Lygodiaceae (Christophel and Greenwood 1987; Conran and Christophel 1998). The lens was dated palynologically as Middle Eocene (Alley 1987), with the original environment considered to be similar to a modern complex notophyll vine forest (Christophel and Greenwood 1987).

Examination of the Golden Grove clays for seeds and fruits revealed a number of mostly small ca. $3-5-\mathrm{mm}$ nonde-

\footnotetext{
${ }^{1}$ Author for correspondence; e-mail john.conran@adelaide .edu.au.
}

Manuscript received February 2003; revised manuscript received January 2004. script ovoid seeds with possible affinities to Lauraceae but without any distinctive features that would allow assignment to any family with certainty (D. C. Christophel, unpublished observations). However, a single small, distinctively sculptured seed was recovered from the site, bearing close resemblance to the extant carnivorous plant genus Byblis (Byblidaceae).

Byblis Salisb. currently consists of seven species: four annual species from northern Australia (Lowrie and Conran 1998), with Byblis liniflora Salisb. extending to southern New Guinea (van Steenis 1971), and two perennial species from southwestern Australia (Conran et al. 2002; Conran and Carolin 2004). Studies of seed morphology in Byblis have shown that seed morphology is a highly useful character at species level, with a range of useful sculpturing and other seed coat features helping to define the different taxa (Lowrie and Conran 1998; Conran et al. 2002).

In particular, the annual species form a complex across northern Australia, growing in seasonally inundated places and surviving the dry season as soil-buried seed. As such, they might be expected to be ideal candidates for preservation in a depositional environment. However, because the majority have seeds less than a millimeter in length, they could easily be overlooked. Most recent studies of Tertiary seeds from Australia have dealt with relatively large seeded or fruited taxa (Rozefelds 1991, 1995; Rozefelds and Christophel 1996a, 1996b; Greenwood et al. 2000, 2001; Dettmann and Clifford 2001), but there are currently no seeds or fruits described from the Golden Grove site. Because there is no prior fossil record for the Byblidaceae (micro- or macrofossil), the seed is described here, and its affinities with extant Byblis species are discussed. 

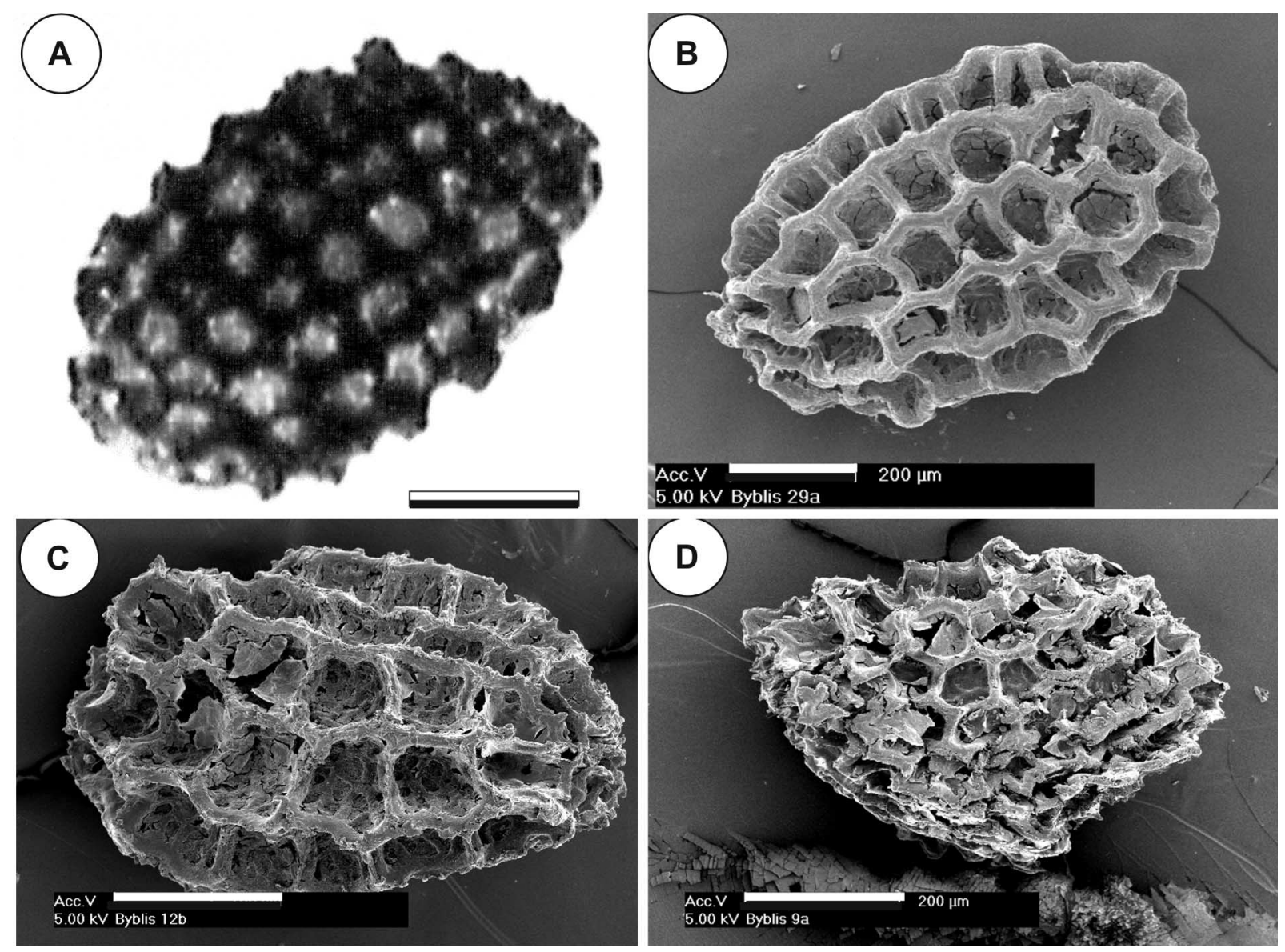

Fig. 1 Golden Grove Byblidaceae fossil and seeds of similar extant Byblis species for comparison. A, Golden Grove Byblidaceae seed Molenaar s.n. (ADU, destroyed; represented by the photograph); scale bar $=200 \mu \mathrm{m}$. B, Byblis filifolia A. Lowrie 2041 (PERTH). C, Byblis liniflora A. Lowrie 1320 (PERTH). D, Byblis rorida R.L. Barrett 595 (PERTH). B-D all to indicated scales.

\section{Material and Methods}

Pieces of fossiliferous clay matrix were placed in a $2 \%-3 \%$ aqueous solution of hydrogen peroxide at ca. $60^{\circ} \mathrm{C}$ and allowed to disaggregate. After removal of any leaf or other large fragments, the sediment was sieved through a series of progressively smaller mesh sizes and then washed with distilled water. The resulting macerate was examined under a dissecting microscope, and any recognizable seeds were removed and digitally photographed. The samples were then stored at the University of Adelaide Palaeobotany collection (ADU) in vials containing a $1 \%$ phenol $50 \%$ ethanol mixture. Unfortunately, there was a disaster where a tray of extracted small to minute fossil seeds and cuticles (including the fossil) was accidentally dropped, smashing them. This happened shortly after the seed had been imaging using light microscopy but before SEM or anatomical investigation could occur. As a result, the only extant record of the taxon is the photograph presented here. Nevertheless, there is sufficient detail in the image to indicate its affinities to Byblidaceae.
The difficulty with formally naming the fossil is the loss of the type other than as a photograph. Under the St. Louis version of international code of botanical nomenclature, Article 8.5 states that the type of "the name of a fossil plant of the rank of species or below is always a specimen" (Greuter et al. 2000, p. 11). Similarly, Article 9.13 states: "the holotype or lectotype of a name of a species or infrataxon of fossil plants is the specimen (or one of the specimens) on which the validating illustrations are based" (p. 15). Because the designation of a formal name for the fossil would result in a nomen invalidum under the current code, the specimen is hereby assigned to Byblidaceae but described as a parataxon.

Seeds of wild collected populations of Byblis aquatica Lowrie \& Conran from the Northern Territory, Byblis filifolia from the Kimberley or Western Australia, Byblis liniflora from northern Queensland and Byblis rorida Conran \& Lowrie from the Kimberley (voucher details listed in Conran et al. 2002) were examined under SEM and stereo dissecting microscope for size and sculpturing comparisons. Description 
Table 1

Seed Character Data for the Golden Grove Byblidaceae Fossil and the Extant Annual Northern Australian Species Byblis aquatica, Byblis filifolia, Byblis liniflora, and Byblis rorida (modified from Conran et al. 2002)

\begin{tabular}{|c|c|c|c|c|c|}
\hline Character & $\begin{array}{c}\text { Golden Grove } \\
\text { Byblidaceae }\end{array}$ & B. liniflora & B. filifolia & B. aquatica & B. rorida \\
\hline Length (mm) & 0.7 & $0.5-0.9(0.7)$ & $0.4-1.1(0.7)$ & $0.9-1.3(1.0)$ & $0.5-0.8(0.6)$ \\
\hline Width (mm) & 0.45 & $0.4-0.6(0.5)$ & $0.3-0.8(0.5)$ & $0.4-0.7(0.6)$ & $0.4-0.6(0.5)$ \\
\hline Longitudinal ridges & Denticulate & Minutely denticulate & Denticulate & Smooth, prominent & Minutely denticulate \\
\hline Transverse ridges & Shallow & Shallow & Deep & Absent & Shallow \\
\hline $\begin{array}{l}\text { Anticlinal wall } \\
\text { sculpturing }\end{array}$ & Verrucate & $\begin{array}{l}\text { Tuberculate- } \\
\text { verrucate }\end{array}$ & Smooth & Smooth & $\begin{array}{l}\text { Irregularly } \\
\quad \text { roughened }\end{array}$ \\
\hline Cell length $(\mu \mathrm{m})$ & $90-140(110)$ & 73-165 (119) & 57-178 (120) & $114-150(130)$ & $54-74(66)$ \\
\hline Cell width $(\mu \mathrm{m})$ & $80-120(90)$ & 68-104 (88) & $42-132(82)$ & $10-78(66)$ & $52-65(60)$ \\
\hline Periclinal walls & Unclear & Foveolate & Foveolate & Smooth & Smooth \\
\hline
\end{tabular}

Note. Numbers in parentheses represent mean values.

and comparisons of the seed follow the features used by Lowrie and Conran (1998) and Conran et al. (2002).

\section{Systematics}

Order-Lamiales

Family_Byblidaceae (Engler \& Gilg.) K. Domin.

Parataxon. Golden Grove Byblidaceae seed.

Locality. East Yatala Sand Pit, Golden Grove, South Australia $\left(138^{\circ} 43^{\prime} 30^{\prime \prime} \mathrm{E}, 34^{\circ} 47^{\prime} 10^{\prime \prime} \mathrm{S}\right)$.

Stratum. Base of the Proteacidites pachypolis Zone of the Tertiary southern Australian palynological zone (Alley 1987). Age. Middle Eocene.

Description. Seed small $(0.7 \mathrm{~mm}$ long and $0.45 \mathrm{~mm}$ wide), black, elliptical, ends rounded, micropylar end slightly more acute. Testal cells 7-9 along the long axis and 4-6 across; cells 90-140 $\mu \mathrm{m}$ long and 80-120 $\mu \mathrm{m}$ wide (mean $110 \times 90 \mu \mathrm{m})$. Testa reticulately honeycombed; longitudinal ridges minutely denticulate-crenulate; transverse ridges shallow. Periclinal walls deeply concave; anticlinal wall ridges verrucate (fig. $1 A$ ).

\section{Discussion}

Comparison of the fossil with extant Byblis taxa immediately rules out the perennial temperate species because their seeds have prominent ribbed lamellar or muricate processes (Conran et al. 2002). Among the tropical annual species, $B y$ blis aquatica has conspicuous longitudinal furrows and ridges and is very different from the Golden Grove fossil (table 1), which more closely resembles seed of Byblis filifolia (fig. 1B), Byblis liniflora (fig. 1C), and Byblis rorida (fig. 1D). The verrucate anticlinal ridges resemble those of $B$. liniflora and $B$. rorida (the ridges in $B$. filifolia are smooth), and the size of the fossil seed and lack of obvious irregular anticlinal roughening places it closest to B. liniflora (table 1). Nevertheless, in the absence of a number of representative seeds of the fossil to allow sculpturing and size variability to be assessed, care must be taken in placing it with an extant taxon. Similarly, because the extant species are differentiated on anther, gland, and chromosomal characters in addition to seed size and testal sculpturing, the fossil can be placed only into the B. liniflora complex.

Byblis is not the only tropical Australian marsh plant producing abundant small black reticulately sculptured seeds. In particular, many of the carnivorous Drosera L. and Utricularia L. (Lentibulariaceae) with which Byblis grows also have small sculptured seeds (Dwyer 1983; Taylor 1989). In particular, Drosera indica L. (Droseraceae), which, like the tropical Byblis species with which it grows, is an annual carnivorous plant from ephemeral soaks, pond, and creek margins, also shows considerable variation in seed morphology and sculpturing across northern Australia (Susandarini 2001; Susandarini et al. 2002). However, although D. indica mostly shows reticulate honeycombing, the seeds are ovoid-elliptical, tapering at the micropylar end, and the periclinal sculpturing and anticlinal concavities are very different from the fossil (see illustrations in Susandarini et al. 2002), ruling it out as a possible candidate for affinities with the fossil. Similarly, the seed coat patterns seen in other Australian carnivorous plants do not match those of the Byblidaceae (Dwyer 1983; Taylor 1989).

The clay lens at Golden Grove possibly represents an oxbow lake and is thought to have been surrounded by complex notophyll vine forest similar to that seen in extant rainforests in north Queensland (Christophel and Greenwood 1987). Providing there is good light, Byblis is often a common taxon around such pondages and along creeks, especially where drawdown during the dry season exposes the mud for colonization by herbaceous annuals (Lavarack 1981; Lowrie 1998). Thus, if there was a dry season resulting in drawdown at the Golden Grove site (which occurs even in the wet tropics of present-day north Queensland), the palaeoenvironment would have been ideal for Byblidaceae species, further supporting the identification of the seed.

\section{Acknowledgments}

Monier Ltd. are thanked for access to the Monier East Yatala Sand Pit, Golden Grove, South Australia. Trudy Molenaar is thanked for the maceration and sorting of the 
specimens as part of studies toward an honors degree in the then Department of Botany (now Environmental Biology) at the University of Adelaide. Professor Dr. Werner Greuter
(Botanic Garden and Botanical Museum Berlin-Dahlem) is thanked for his extremely helpful advice regarding the nomenclatural issues raised by the loss of the type specimen.

\section{Literature Cited}

Alley NF 1987 Middle Eocene age of the megafossil flora at Golden Grove, South Australia: preliminary report and comparison with the Maslin Bay flora. Trans R Soc S Aust 111: 211-212.

Christophel DC, DR Greenwood 1987 A megafossil flora from the Eocene of Golden Grove, South Australia. Trans R Soc S Aust 111: $155-162$.

1988 A comparison of Australian tropical rainforest and Tertiary fossil leaf-beds. Proc Ecol Soc Aust 15:139-148.

Christophel DC, WK Harris, AK Syber 1987 The Eocene flora of the Anglesea locality, Victoria. Alcheringa 11:303-323.

Christophel DC, LJ Scriven, DR Greenwood 1992 An Eocene megafossil flora from Nelly Creek, South Australia. Trans R Soc S Aust 116:65-76.

Conran JG, RC Carolin 2004 Byblidaceae. Pages 45-49 in J Kadereit, ed. The families and genera of vascular plants. Vol 7. Dicotyledons: Lamiales. Springer, Berlin.

Conran JG, DC Christophel 1998 Paracordyline aureonemoralis (Lomandraceae): an Eocene monocotyledon from South Australia. Alcheringa 22:351-359.

Conran JG, A Lowrie, J Moyle-Croft 2002 A revision of Byblis (Byblidaceae) in south-western Australia. Nuytsia 15:11-20.

Dettmann ME, HT Clifford 2001 The fossil record of Elaeocarpus L. fruits. Mem Queensl Mus 46:461-497.

Dwyer TP 1983 Seed structure in carnivorous plants. Carniv Plant Newsl 12:8-22, 33-38, 45-50.

Greenwood DR 1996 Eocene monsoon rainforests in central Australia? Aust Syst Bot 9:95-112.

Greenwood DR, PW Haines, DC Steart 2001 New species of Banksieaeformis and a Banksia "cone" (Proteaceae) from the Tertiary of central Australia. Aust Syst Bot 14:871-890.

Greenwood DR, AJ Vadala, JG Douglas 2000 Victorian Paleogene and Neogene macrofloras: a conspectus. Proc R Soc Vic 112:65-92.

Greuter W, J McNeill, FR Barrie, H-M Burdet, V Demoulin, TS Filgueiras, DH Nicolson, et al, eds 2000 International code of botanical nomenclature (Saint Louis code) adopted by the Sixteenth
International Botanical Congress, St. Louis. July-August 1999. Koeltz Scientific, Königstein. 474 pp.

Hill RS 1982 The Eocene megafossil flora of Nerriga, New South Wales, Australia. Palaeontogr B 181:44-77.

-, ed 1994 History of the Australian vegetation: Cretaceous to recent. Cambridge University Press, Cambridge. 433 pp.

Hill RS, T Brodribb 2001 Macrofossil evidence for the onset of xeromorphy in Australian Casuarinaceae and tribe Banksieae (Proteaceae). J Mediterr Ecol 2:127-136.

Lavarack PS 1981 The northern rainbow plant Byblis liniflora. Carniv Plant Newsl 10:102-103.

Lowrie A 1998 Carnivorous plants of Australia. Vol 3. University of Western Australia Press, Perth. 288 pp.

Lowrie A, JG Conran 1998 A taxonomic revision the genus Byblis (Byblidaceae) in northern Australia. Nuytsia 12:59-74.

Rozefelds AC 1991 Mid-Tertiary Sacropetalum (Menispermaceae) from Glencoe, mid-eastern Queensland. Alcheringa 15:145-150.

1995 Miocene Wilkinsonia fruits (Hicksbeachiinae, Proteaceae) from the base of the Yallourn Formation, Latrobe Valley, Victoria. Pap Proc R Soc Tasman 129:59-62.

Rozefelds AC, DC Christophel 1996 a Elaeocarpus (Elaeocarpaceae) endocarps from the Early to Middle Miocene Yallourn formation of Eastern Australia. Muelleria 9:229-237.

1996 Elaeocarpus (Elaeocarpaceae) endocarps from the Oligo-Miocene of Eastern Australia. Pap Proc R Soc Tasman 130: $41-48$.

Susandarini R 2001 Investigation of the population variation of Drosera indica L. complex using combined morphological and molecular techniques. MS diss. Adelaide University.

Susandarini R, GG Collins, A Lowrie, JG Conran 2002 Morphological variation within the Drosera indica (Droseraceae) complex in northern Australia. Aust J Bot 50:207-214.

Taylor P 1989 The genus Utricularia: a taxonomic monograph. HMSO, London. 724 pp.

van Steenis CGGJ 1971 Byblidaceae. Flora Malesiana Bull Suppl Ser I 7:135-137. 